\title{
THE IMPACT OF HYDROXYCITRIC ACID ON THE LIPID METABOLISM PROFILE UNDER EXPERIMENTAL INSULIN RESISTANCE SYNDROME OF SYRIAN HAMSTERS
}

\author{
A. L. ZAGAYKO, A. I. SHKAPO, V. P. FYLYMONENKO, T. O. BRIUKHANOVA \\ National University of Pharmacy, Kharkiv, Ukraine; \\ e-mail:vpfylymonenko@gmail.com
}

The syndrome of insulin resistance (IR) is one of the leading reasons for the increased risk of cardiovascular diseases and their complications. Among the key components of IR are obesity and dyslipidemia. Hydroxycitric acid (HCA), an inhibitor of a key enzyme of lipogenesis ATP citrate lyase (ACLY) is a promising obesity treatment agent. The aim of this work was to investigate the effect of HCA on lipid and lipoproteins content in the blood serum, as well as lipid content and activity of some lipid metabolism enzymes in the liver of hamsters with IR. IR was modeled by keeping animals on high-fat diet with addition of fructose. Lipid content was determined by using standard reagent kits, the level of lipoproteins, the activity of glucose 6-phosphate dehydrogenase and ACLY - spectrophotometrically, lysosomal lipase activity - fluorimetrically. Development of hyperlipidemia and atherogenic dyslipidemia, lipid accumulation in the liver, activation of lysosomal lipase and ACLY and reduction of glucose 6-phosphate dehydrogenase activity were shown under IR. The treatment by HCA reduces the manifestations of hyperlipidemia, but enhances the lipid accumulation in the liver.

Ke y word s: ATP-citrate lyase, hydroxycitric acid, insulin resistance, dyslipidemia, hepatic lipidosis.

I nsulin resistance syndrome (one of the key metabolic syndrome components) is the most common systemic disease characterized by disturbance of all types of metabolism, and high risk of complications associated with cardiovascular system impairment. Great social significance of this disease is that it leads to early disability and high mortality. Some of the key components of insulin resistance are obesity and dyslipidemia [1].

ATP-citrate lyase (ACLY) is a key lipogenesis enzyme that converts citrate into acetyl-CoA in the cytoplasm; acetyl-CoA is an initial precursor that after connection of carboxyl group gives a malonylCoA for the fatty acids biosynthesis. Cytosolic citrate is a derivative of the mitochondrial tricarboxylic cycle, that is why ACLY catalyzes a critical reaction which connects glucose catabolism and lipid synthesis [2].

Lipogenesis is a metabolic pathway that is coordinately regulated in the response to nutritional and hormonal stimuli. It has been shown that dysregulation of lipogenesis significantly contributes to the occurrence of dyslipidemia and metabolic disorders [3]. At the same time, the metabolic contribution of each separate lipogenic enzyme in lipid metabolism and also in whole body energy homeostasis is poorly understood [4-6].

According to the literature, the amount of both acetyl-CoA and malonyl-CoA is markedly decreased in liver, irrespective of dietary fat intake, and also the level of triacylglycerol and free fatty acids drop in the blood with ACLY knockout. On this background the liver lipid range also changes [2].

Among the drugs and functional foodstuffs that are used to the obesity treatment, the popularity of products from Garcinia Cambogia (Garcinia gummi-gutta L.) is coming up now; hydroxycitric acid (HCA) is an active substance of mentioned Garcinia products. The proposed mechanism of HCA action lies in a competitive ACLY inhibition, but the experimental studies of Garcinia drugs are isolated cases $[7,8]$.

Based on the above, the exploration of ACLY activity and lipid metabolism profile using the hydroxycitric acid appears to be topical.

\section{Materials and Methods}

24 male Syrian hamsters (Mesocricetus auratus L.) at the age of 20 weeks at the beginning of experiment were used. Animals have been divided 
into 3 groups by 8 in each one: 1) intact animals that were kept on a standard diet 2) group of animals with insulin resistance syndrome (IR) - group which diet contained $29 \%$ of animal fat [9] with addition of fructose (2.5 g/100 g of body weight per day) [10], 5 weeks (IR group) 3) animals which have been administered intragastrically the HCA (STIFIMOL preparation manufactured by Kyiv Vitamin Factory) at the daily dose of $5 \mathrm{mg} / \mathrm{kg}$ body weight starting from $3^{\text {rd }}$ week of insulin resistance syndrome modelling (IR+ST group). After 5 weeks the animals were decapitated under chloralose-urethane anesthesia. The studies were conducted in accordance with national General ethical principles of animal experiments (Ukraine, 2001), which are consistent with provisions of the European Convention for the Protection of Vertebrate Animals used for Experimental and other Scientific Purposes (Strasbourg, 1986).

The studied objects were the blood serum and liver of laboratory animals. A 25\% homogenate and postmitochondrial and mitochondrial fractions were prepared from perfused liver by differential centrifugation.

The development of IR was confirmed by the blood serum level of glucose and insulin in fasting state, calculating insulin resistance index using the algorithm Homeostasis Model Assessment (the data are not included in the article).

Total lipids concentration was determined using a standard kit (Eagle Diagnostics, USA) in a reaction with vanillic reagent. The content of triacylglycerols was determined using a standard enzymatic glyceroloxidase assay kit (KONE Oy, Finland). Total cholesterol content was determined by standard enzymatic cholesteroloxidase kit (Boehringer Mannheim GmbH diagnostica, Germany). The content of free fatty acids (FFA) was determined using colorimetric method [11].

Lipoproteins of blood serum were fractionated by disc electrophoresis in vertical polyacrylamide gel plates $(160 \times 140 \times 2 \mathrm{~mm})$ [12]. $\alpha$-lipoprotein, pre- $\beta$ - and $\beta$-lipoproteins, the amount of which is called apo-B-containing lipoproteins were identified at the electropherograms. Stained by black sudan 10 lipoproteins were eluted, the light absorption of eluate was measured spectrophotometrically at $595 \mathrm{~nm}$ [13].

The activity of glucose 6-phosphate dehydrogenase (G-6-PDG, EC 1.1.1.49) was determined spectrophotometrically by $\mathrm{NADP}^{+}$reduction [14]. The activity of lysosomal acid lipase (LL, EC 3.1.1.3) was determined in lysosomal-mitochondrial liver fraction by the hydrolysis of substrate - 4-methylumbelliferyl oleate; hydrolysis product content was determined fluorimetrically $(\mathrm{E}=449 \mathrm{~nm}, 410 \mathrm{~nm})$ [15]. The activity of ATP-citrate lyase (ACLY, EC 4.1.3.8) was determined using malate dehydrogenase associated method by the reduced NADH that is oxidized by oxaloacetate formed in cytrate lyase reaction [16]. Protein content was determined by the Lowry method in the Miller modification.

Statistical analysis of the data was performed using Statistica software package (StatSoft Inc., USA, version 6.0). The significance of differences between groups was assessed by non-parametric Mann-Whitney test.

\section{Results and Discussion}

Keeping animals on the described diet for 5 weeks led to insulin resistance development, which was confirmed by insulin resistance index increasing 2.6 times in the parallel experiment (3.02 vs 1.78 in the intact animals).

The obtained data are the evidence that high energy diet lead to the hyper- and dyslipidemia that are the typical signs of IR (Table 1): the content of total lipids (TL) (mainly due to neutral lipids), lipoproteins (due to apo-B-containing ones) and nonesterified fatty acids are increased in the blood of experimental animals. Level of high-density lipoproteins (HDL) is somewhat reduced in this case.

All these changes have the pronounced proatherogenic character and may point the lipid metabolism shift in animal's organism towards the lipids accumulation and adipose tissue redistribution in favor of the visceral one. The latter fact is confirmed by free fatty acids (FFA) accumulation in blood, at that the main FFA source in metabolic syndrome is lipolysis activation in adipose tissue. The use of HCA significantly reduces all the studied parameters, except FFA and total cholesterol (TC), their content remains increased. Such changes are the indicators of: $1^{\text {st }}$, the fatty acids source in the serum is not their synthesis de novo that should be slightly suppressed by HCA action, but the active lipolysis, and $2^{\text {nd }}$, more complex cholesterol metabolism regulation exists along with its synthesis from components of non-carbohydrate nature.

The assumption about predominant role of lipolysis activation in FFA release into blood under high-caloric diet condition is supported by the data of lysosomal acid lipase activity in the liver of experimental animals (Table 2). This activity increased 
Ta ble 1. Some parameters of lipid metabolism in Syrian hamsters males serum with insulin resistance syndrome (IR group) and under hydroxycitric acid administration (IR+ST group) $(M \pm m, n=8)$

\begin{tabular}{l|c|c|c}
\hline \multirow{2}{*}{\multicolumn{1}{c|}{ Parameters }} & \multicolumn{3}{|c}{ Group of animals } \\
\cline { 2 - 4 } & Intact animals & IR & IR+ST \\
\hline Total lipids, $\mathrm{mg} / \mathrm{ml}$ & $6.25 \pm 0.39$ & $7.29 \pm 0.21^{*}$ & $5.78 \pm 0.22^{* *}$ \\
Free fatty acids, mmol/l & $1.64 \pm 0.16$ & $2.29 \pm 0.25^{*}$ & $2.08 \pm 0.15^{*}$ \\
Triacylglycerols, $\mathrm{mg} / \mathrm{ml}$ & $1.57 \pm 0.22$ & $2.00 \pm 0.13^{*}$ & $1.36 \pm 0.11^{* *}$ \\
Total cholesterol, mmol/l & $2.84 \pm 0.15$ & $3.71 \pm 0.18^{*}$ & $3.56 \pm 0.19^{*}$ \\
Total lipoproteins, $\mathrm{mg} / \mathrm{ml}$ & $6.72 \pm 0.33$ & $7.77 \pm 0.18^{*}$ & $6.89 \pm 0.37^{* *}$ \\
ApoB- lipoproteins, $\mathrm{mg} / \mathrm{ml}$ & $5.66 \pm 0.34$ & $6.68 \pm 0.21^{*}$ & $5.32 \pm 0.28^{* *}$ \\
High-density lipoproteins, $\mathrm{mg} / \mathrm{ml}$ & $1.01 \pm 0.02$ & $0.85 \pm 0.08^{*}$ & $1.15 \pm 0.07^{* *}$ \\
\hline
\end{tabular}

Here and in Table 2: * the differences are substantial as related to intact animals $(P \leq 0.05) ; * *$ the differences are substantial as related to IR group $(P \leq 0.05)$.

2.35-fold compared to the intact animals and remained high when HCA was used.

As for lipogenesis inhibition that occurs because of decreased carbohydrate-derived substrates flux due to HCA usage, it correlates with a decrease of G-6-PDG activity observed under experimental IR condition and amplified under STIFIMOL action (Table 2).

We obtained data on the decrease of ACLY activity under the STIFIMOL usage (Table 2), and they confirm the assumption about HCA effect realization by virtue of this enzyme inhibition. The consequence of such action should be a switching the FFA synthesis (and, to some extent, cholesterol as well) to non-carbohydrate sources of acetyl-CoA, particularly to FFA resynthesis from food lipids.

It is needed to pay attention to the increase of total lipid level in the liver tissue, particularly tria- cylglycerols (TAG) accumulation which is observed in animals received the energy food and this accumulation is strengthened by the HCA administration (Table 2). Such effect under IR conditions is probably a result of the FFA utilization that come to the liver from blood in the context of active lipolysis and leads to secretion of lipoproteins (LP) enriched by TAG and serves as additional pro-atherogenic factor. Since a secretion of apo-B-containing LP is apparently somewhat reduced at the HCA application (Table 1), TAG accumulation in the liver can lead to lipidosis, and later to hepatic steatosis. Perhaps, more significant LL activation at the HCA administration as compared to model pathology group (Table 2) is an attempt to compensate for TAG accumulation through their degradation and oxidation.

The dangerous consequence of HCA usage is a decrease of cholesterol content in liver that does

Ta ble 2. Some parameters of lipid metabolism in Syrian hamsters males liver with insulin resistance syndrome (IR group) and under hydroxycitric acid administration (IR+ST group) ( $M \pm m, n=8)$

\begin{tabular}{l|c|c|c}
\hline \multirow{2}{*}{\multicolumn{1}{c|}{ Parameters }} & \multicolumn{3}{c}{ Group of animals } \\
\cline { 2 - 4 } & Intact animals & IR & IR+ST \\
\hline Total lipids, mg/g & $112.62 \pm 2.66$ & $143.59 \pm 2.65^{*}$ & $177.32 \pm 1.56^{* * * *}$ \\
Triacylglycerols, mg/g & $15.95 \pm 1.23$ & $25.01 \pm 1.18^{*}$ & $32.12 \pm 1.22^{* * * *}$ \\
$\begin{array}{l}\text { Total cholesterol, mcmol/g } \\
\text { Activity of glucose 6-phosphate } \\
\text { dehydrogenase, nmol/mg·min }\end{array}$ & $5.15 \pm 0.25$ & $7.25 \pm 0.18^{*}$ & $4.98 \pm 0.25^{* *}$ \\
$\begin{array}{l}\text { Activity of lysosomal acid } \\
\text { lipase, nmol/mg·min }\end{array}$ & $4.44 \pm 0.28$ & $3.13 \pm 0.28^{*}$ & $2.29 \pm 0.25^{* * * *}$ \\
$\begin{array}{l}\text { Activity of ATP-citrate lyase, } \\
\text { mcmol NADH/mg·min }\end{array}$ & $0.54 \pm 0.03$ & $1.27 \pm 0.09^{*}$ & $1.45 \pm 0.12^{*}$ \\
\hline
\end{tabular}


not correspond to increased cholesterol level in the blood (Tables 1-2). Obviously, these changes are a manifestation of active transport of cholesterol (as esters) to the tissues, and such transport probably performs within the lipoproteins hydrophobic phase due to lack of triglycerides, and can be considered as unfavorable atherogenic factor and evidence of a disturbance of the cholesterol usage for the synthesis of biologically active steroids that may have postponed negative consequences.

Thus, application of hydroxycitric acid (ACLY inhibitor) under the experimental IR is characterized by ambivalent action: on the one hand, it causes the decrease of hyperlipidemia manifestations and therefore can have somewhat adjusted the signs of lipid toxicity that are typical for IR, but on the other hand, this compound does not exhibit the inhibitory effect on lipolysis, it may further distort the distinct parts of lipid metabolism and cause the TAG accumulation in the liver, which in turn leads to hepatic lipidosis. Given the obtained experimental data, it may be concluded that further careful investigation of the HCA effect on the various organism systems and the application terms to avoid possible adverse effects is needed.

\section{ВПЛИВ ГІДРОКСИЛИМОННОЇ КИСЛОТИ НА ПОКАЗНИКИ МЕТАБОЛІЗМУ ЛІПІДІВ У СИРІЙСЬКИХ ХОМ'ЯЧКІВ ЗА ЕКСПЕРИМЕНТАЛЬНОГО СИНДРОМУ ІНСУЛІНОРЕЗИСТЕНТНОСТІ}

\section{А. Л. Загайко, А. I. Шкапо, \\ В. П. Филимоненко, Т. О. Брюханова}

\section{Національний фармацевтичний університет, Харків, Україна; e-mail: vpfylymonenko@gmail.com}

Синдром інсулінорезистентності (IP) $є$ одним із визначальних у зростанні серцево-судинних захворювань та їхніх наслідків. Ключовими компонентами IP є ожиріння та дисліпідемія. Гідроксилимонна кислота (ГЛК) - інгібітор ключового ензиму ліпогенезу АТР-цитратліази (АЦЛ) - перспективний коректор ожиріння. Метою роботи було дослідити вплив ГЛК на вміст ліпідів та ліпопротеїнів у сироватці крові хом'ячків, а також на вміст ліпідів й активність деяких ензимів ліпідного обміну в печінці тварин за IP. Синдром IP моделювали, утримуючи тварин на високожировій дієті 3 додаванням фруктози. Ліпіди визначали за допомогою стандартних наборів реактивів, рівень ліпопротеїнів, активність глюкозо-6-фосфатдегідрогенази та АЦЛ - спектрофотометрично, активність лізосомальної ліпази - флуориметрично. Виявлено розвиток гіперліпідемії та атерогенної дисліпідемії, накопичення ліпідів у печінці, активацію лізосомальної ліпази й АЦЛ і зниження активності глюкозо-6-фосфатдегідрогенази за IP. Застосування ГЛК зменшувало прояви гіперліпідемії, але підсилювало накопичення ліпідів у печінці.

К л юч о в слов а: АТР-цитратліаза, гідроксилимонна кислота, інсулінорезистентність, дисліпідемія, печінковий ліпідоз.

\section{ВЛИЯНИЕ ГИДРОКСИЛИМОННОЙ КИСЛОТЫ НА ПОКАЗАТЕЛИ МЕТАБОЛИЗМА ЛИПИДОВ У СИРИЙСКИХ ХОМЯЧКОВ ПРИ ЭКСПЕРИМЕНТАЛЬНОМ СИНДРОМЕ ИНСУЛИНОРЕЗИСТЕНТНОСТИ}

\section{А. Л. Загайко, А. И. Шкапо, \\ В. П. Филимоненко, Т. А. Брюханова}

Национальный фармацевтический университет, Харьков, Украина; e-mail: vpfylymonenko@gmail.com

Синдром инсулинорезистентности (ИР) является одним из определяющих рост сердечно-сосудистых заболеваний и их последствий. Ключевыми компонентами ИР являются ожирение и дислипидемия. Гидроксилимонная кислота (ГЛК) - ингибитор ключевого энзима липогенеза АТР-цитратлиазы (АЦЛ) - перспективный корректор ожирения. Целью работы было исследовать влияние ГЛК на содержание липидов и липопротеинов в сыворотке крови хомячков, а также на содержание липидов и активность некоторых энзимов липидного обмена в печени животных с ИР. Синдром ИР моделировали, содержа животных на высокожировой диете с добавлением фруктозы. Липиды определяли с помощью стандартных наборов реактивов, уровень липопротеинов, активность глюкозо6-фосфат-дегидрогеназы и АЦЛ - спектрофотометрически, активность лизосомальной ли- 
пазы - флуориметрически. Выявлены развитие гиперлипидемии и атерогенной дислипидемии, накопление липидов в печени, активация лизосомальной липазы и АЦЛ и снижение активности глюкозо-6-фосфат-дегидрогеназы при ИР. Применение ГЛК уменьшало проявления гиперлипидемии, но усиливало накопление липидов в печени.

К л ю че в ы е с ло в а: АТР-цитратлиаза, гидроксилимонная кислота, инсулинорезистентность, дислипидемия, печеночный липидоз.

\section{References}

1. Han TS, Lean ME. A clinical perspective of obesity, metabolic syndrome and cardiovascular disease. JRSM Cardiovasc Dis. 2016; 5: 1-13.

2. Wang Q, Li S, Jiang L, Zhou Y, Li Z, Shao M, Li W, Liu Y. Deficiency in hepatic ATP-citrate lyase affects VLDL-triglyceride mobilization and liver fatty acid composition in mice. J Lipid Res. 2010; 51(9): 2516-2526.

3. Zagayko AL, Briukhanova TO, Shkapo AI. Some characteristics of lipids and lipoproteinies metabolism in Syrian hamsters females of different age under the experimental metabolic syndrome. World Med Biol. 2015; 52(3): 99-103. (In Ukrainian).

4. Lewis GF, Carpentier A, Adeli K, Giacca A. Disordered fat storage and mobilization in the pathogenesis of insulin resistance and type 2 diabetes. Endocr Rev. 2002; 23(2): 201-229.

5. Browning JD, Horton JD. Molecular mediators of hepatic steatosis and liver injury. J Clin Invest. 2004; 114(2): 147-152.

6. Donnelly KL, Smith CI, Schwarzenberg SJ, Jessurun J, Boldt MD, Parks EJ. Sources of fatty acids stored in liver and secreted via lipoproteins in patients with nonalcoholic fatty liver disease. J Clin Invest. 2005; 115(5): 1343-1351.

7. Vasques CA, Schneider R, Klein-Júnior LC, Falavigna A, Piazza I, Rossetto S. Hypolipemic effect of Garcinia cambogia in obese women. Phytother Res. 2014; 28(6): 887-891.

8. Hayamizu K, Ishii Y, Kaneko I, Shen M, Okuhara Y, Shigematsu N, Tomi H, Furuse M, Yoshino G, Shimasaki H. Effects of garcinia cambogia (Hydroxycitric Acid) on visceral fat accumulation: a double-blind, randomized, placebo-controlled trial. Curr Ther Res Clin Exp. 2003; 64(8): 551-567.

9. Wang PR, Guo Q, Ippolito M, Wu M, Milot D, Ventre J, Doebber T, Wright SD, Chao YS. High fat fed hamster, a unique animal model for treatment of diabetic dyslipidemia with peroxisome proliferator activated receptor alpha selective agonists. Eur J Pharmacol. 2001; 427(3): 285-293.

10. Jurgoński A, Juśkiewicz J, Zduńczyk Z. A highfat diet differentially affects the gut metabolism and blood lipids of rats depending on the type of dietary fat and carbohydrate. Nutrients. 2014; 6(2): 616-626.

11. Prokhorov MIu, Tiunov MP, Shakalis DA. Simple colorimetric micromethod of determination of free fatty acids. Lab Delo. 1977; (9): 535-536. (In Russian).

12. Kolb VG, Kamyshnikov VS. Quantitative study of serum lipoproteins in healthy persons by polyacrylamide gel disc electrophoresis. Lab Delo. 1979; (1): 42-44. (In Russian).

13. Kaliman PA, Zagayko AL, Shalamov RV, Ganusova GV, Barannik TV, Skripnik EV, Sokolik VV, Shabi BK. Content and composition of lipoproteins of rat blood and liver and various parameters of oxidative stress during administration of cobalt chloride. Ukr Biokhim Zhurn. 1997; 69(5-6): 138-148. (In Russian).

14. Putilina FE, Zoidze SD. Methods of biochemical research (lipid and energy metabolism). Under ed. Prokhorova MI. Leningrad: Publishing House of Leningrad University, 1982. P. 168172. (In Russian).

15. Aslanidis C, Ries S, Fehringer P, Büchler C, Klima H, Schmitz G. Genetic and biochemical evidence that CESD and Wolman disease are distinguished by residual lysosomal acid lipase activity. Genomics. 1996; 33(1): 85-93.

16. Wang Q, Jiang L, Wang J, Li S, Yu Y, You J, Zeng R, Gao X, Rui L, Li W, Liu Y. Abrogation of hepatic ATP-citrate lyase protects against fatty liver and ameliorates hyperglycemia in leptin receptor-deficient mice. Hepatology. 2009; 49(4): 1166-1175.

Received 21.03.2016 